\title{
Factors associated with overweight among elementary schoolchildren in Campinas, São Paulo, Brazil
}

\author{
Fatores associados ao excesso de peso em \\ escolares do ensino fundamental \\ em Campinas, São Paulo
}

Juliana Melo Teruel Biagi CAMARGO'

Leticia MARÍN-LEÓN ${ }^{1}$

\section{A B S T R A C T}

\section{Objective}

To assess overweight/obesity of elementary schoolchildren in Campinas, São Paulo, Brazil, and its association with parental nutritional status, children's food consumption, food preferences, and level of physical activity, and familial socioeconomic status.

\section{Methods}

This case-control study included 509 schoolchildren aged 7 to 10 years. Body mass index Z-score was used to determine nutritional status, defining cases ( $>+1$ Z-score) and controls ( $\geq-2 \leq+1$ Z-score). To address association with overweight/obesity, a conceptual model was established and used for multiple analysis, performed by logistic regression.

\section{Results}

The children had an overweight/obesity frequency of 39.5\%. Multiple analysis adjusted for socioeconomic level showed that overweight/obese children were more likely to eat at the mall $(1.55 ; 95 \% \mathrm{Cl}=1.00-2.40)$, have overweight and obese parents $(\mathrm{OR}=1.71 ; 95 \% \mathrm{Cl}=1.08-2.71$ and $\mathrm{OR}=3.55 ; 95 \% \mathrm{Cl}=2.18-5.80$ respectively), report use of passive school transport $(\mathrm{OR}=1.57 ; 95 \% \mathrm{Cl}=1.04-2.36)$, and consume chicken nuggets on 3 or more days per week $(\mathrm{OR}=3.03 ; 95 \% \mathrm{Cl}=1.32-6.95)$.

\footnotetext{
1 Universidade Estadual de Campinas, Faculdade de Ciências Médicas, Departamento de Saúde Coletiva. R. Tessália Vieira de Camargo,126, Cidade Universitária Zeferino Vaz, 13083-887, Campinas, SP, Brasil. Correspondência para/Correspondence to: L MARÍN-LEÓN. E-mail: <leticia@fcm.unicamp.br>.

Article based on the master's theses of JMTB CAMARGO, titled "O comportamento alimentar de crianças de terceiro grau do ensino fundamental de escolas municipais de Campinas e sua associação com obesidade infantil e baixo consumo de merenda escolar". Universidade Estadual de Campinas; 2014.
} 


\section{Conclusion}

These results support the urgent need of strategies to reduce overweight/obesity and promote its prevention in schoolchildren. Moreover, intervention studies involving parents and addressing environmental factors are important for the development of effective programs.

Keywords: Child. Exercise. Food consumption. Nutritional status. Parents.

\section{RE S U M O}

\section{Objetivo}

Avaliar o sobrepeso/obesidade de escolares do ensino fundamental de Campinas, estado de São Paulo, e sua associação com: estado nutricional dos pais, consumo de alimentos, preferências alimentares, atividade física e condições socioeconômicas da família.

\section{Métodos}

Este estudo caso-controle incluiu 509 escolares de 7 a 10 anos de idade. O índice de massa corporal escore-Z foi utilizado para determinação do estado nutricional, definindo casos ( $>+1$ escore- $Z$ ) e controles $(\geq-2 \leq+1$ escore-Z). Para associação com o excesso de peso, um modelo conceitual foi criado e utilizado para a análise múltipla, realizada por meio de regressão logística.

\section{Resultados}

A frequência de excesso de peso foi de 39,5\%. A regressão múltipla ajustada por nível econômico mostrou que crianças com sobrepeso/obesidade têm maior chance de comer em shopping center (1.55; 95\%Cl=1.00-2.40), ter pais com sobrepeso ou obesos (OR=1.71; 95\% Cl=1.08-2.71 e 3.55; $95 \% \mathrm{Cl}=2.18-5.80$ respectivamente), utilizar meio de transporte escolar passivo (OR=1.57; $95 \% \mathrm{Cl}=1.04-2.36)$ e comer empanado de frango mais de três dias por semana $(O R=3,03$; IC95\%=1,32-6,95).

\section{Conclusão}

Os resultados suportam a necessidade urgente de estratégias para redução e prevenção do excesso de peso entre os escolares. Além disso, estudos de intervenção que envolvam pais e abordem fatores ambientais são importantes para o desenvolvimento de programas eficazes.

Palavras-chave: Criança. Exercício. Consumo de alimentos. Estado nutricional. Pais.

\section{INTRODUCTION}

The alarming increase of childhood obesity has been considered one of the greatest challenges of the $21^{\text {st }}$ century for worldwide public health. In 2010 over 42 million children under 5 years of age were overweight, and more than $80.0 \%$ of these children lived in developing countries ${ }^{1}$. In 1975 Brazil began to conduct effective and representative population surveys, which allowed assessment of the nutritional status of the population, revealing that the main nutritional problem among children was malnutrition². Over the years 1975 to 2009, the nutritional status of Brazilian children changed quickly. Among children aged 5 to 9 years, stunting decreased from 29.3 to $7.2 \%$ in boys and from 26.7 to $6.3 \%$ in girls, and overweight increased from 10.9 to $34.8 \%$ in boys and from 8.6 to $32.0 \%$ in girls.

When compared with other age groups, children aged 5 to 9 years experienced the largest increase in the prevalence of excess weight in the past 35 years, affecting $33.5 \%$ of Brazilian children ${ }^{3}$. Moreover, the importance of childhood overweight and obesity may not only be limited to anthropometric changes, but also to the associated comorbidities, such as hypertension, diabetes Mellitus, hypercholesterolemia, stroke, arthritis, sleep apnea, and asthma, among others ${ }^{4}$. Even psychological issues such as depression, low self-esteem, rejection, and stigmatization are relevant ${ }^{5}$. 
Childhood overweight/obesity are primarily determined by diet quality, weekly food intake frequency, food preferences, sedentary behavior, physical activity, leisure-time physical activity, and familial susceptibility to weight gain ${ }^{6}$. Some important determinants of children's eating habits are family food habits, parental food preferences, household food security, nutrition knowledge, food affordability, and parental nutritional status ${ }^{6}$. In Brazil families have replaced traditional and healthy foods, such as rice and beans ${ }^{7}$, with ultraprocessed products ${ }^{8}$, high in sugar, fat, and sodium, such as fast food snacks, frozen meals, soft drinks, and candies ${ }^{9}$.

Another risk factor for overweight in children is insufficient physical activity, which is related to parental sedentary behavior and avoidance of leisure-time physical activities. Children who are allowed to watch television or play electronic games unrestrictedly may also become overweight/obese ${ }^{10}$.

Although physical activity at school is encouraged during physical education classes and by participation in sports teams ${ }^{11}$, children's participation has decreased. Active transport to school, such as walking or cycling is an important strategy to promote physical activity among school children ${ }^{12}$, but these activities have also decreased ${ }^{13}$. Furthermore, socio-environmental characteristics may promote overweight/obesity. Thus, the increased advertising of ultra-processed foods for children associated with their wide availability and affordability has increased their consumption and decreased the consumption of vegetables and fruits $^{14}$.

Considering the complexity of childhood obesity and its importance as a public health problem, the aim of this study was to assess overweight/obesity in elementary schoolchildren and its association with parental nutritional status, children's food consumption, food preferences, and physical activity, and familial socioeconomic status.

\section{METHODS}

Third-graders from elementary public schools in Campinas (SP) were surveyed in 2013. The present study was analyzed as a case-control study. After the survey was concluded, overweight and obese children were defined as cases, and normal weight children, as controls.

Body weight was measured by Tanita electronic scales, model BF-680 (Arlington Heights, Illinois, United States), with $180 \mathrm{~kg}$ capacity and accurate to $100 \mathrm{~g}$. Height was measured by a Sanny ${ }^{\circledR}$ (São Bernardo do Campo, São Paulo, Brazil) stadiometer, accurate to $1 \mathrm{~mm}$. Body Mass Index (BMI) was calculated and the children were classified according to their BMI Zscore (Z-BMI) ${ }^{15}$ by sex and age using the World Health Organization tables. Nutritional status, according to Z-BMI, was defined as the dependent variable and classified into two categories: normal weight ( $\geq$-2 Z-score $\leq+1$ Z-score) and overweight/ obese $(>+1$ Z-score $\leq+2 Z$ Z-score; and $>+2$ Z-score, respectively $)^{15}$.

According to the Municipal Department of Education, there were 2,011 third-graders in 2013 attending in 41 schools, distributed into five Núcleos de Ação Educativa Descentralizada, which corresponded to the city regions: North, South, East, Southwest, and Northwest ${ }^{16}$. A random sample of 21 of the 41 schools was selected. Of the 21, two did not allow the study and were replaced by two new schools from the same district. All third-graders were invited to participate $(1,029)$, but just those who returned a signed informed consent form and the family questionnaire filled out by a parent were enrolled in the study. The sample was proportional to the number of third-graders in each school and district. After excluding 4 children with Down syndrome and three underweight children, the final sample was composed of 509 students, of which 201 were cases and 308 controls, a case-to-control ratio of 1.5 .

The research included third-graders and their parents. Two questionnaires were used as instruments, one for parents and one for students. 
The self-administered parental questionnaire was designed by the researchers using several questionnaires and articles, 17-20, and covered: 1) demographic and socioeconomic characteristics (sex; parental schooling; number of household dwellers; household items: refrigerator, washing machine, computer, internet, car, motorcycle); 2) parental chronic diseases (diabetes, hypertension, hypercholesterolemia, hypertriglyceridemia) and gestational weight gain; 3) environmental characteristics (fast-food restaurants in the neighborhood); 4) child's weekly food intake frequency (French fries, flavored snacks, noodles, chicken nugget, cookies, candies/sweets, soft drinks, ultra-processed fruit juice, powdered juice, fruits, fresh and cooked vegetables, salads, and milk - the first nine were chosen as markers of an unhealthy diet, and the last four, a healthy diet); 5) adult physical activity (walking and playing sports), 6) adult anthropometric measurements (self-reported weight and height) were used to calculate the parental BMI [BMI = weight $(\mathrm{kg}) /$ height $\left.\left(\mathrm{m}^{2}\right)\right]$.

The students' self-administered food preferences and physical activity questionnaire was based on the Pesquisa Nacional de Saúde do Escolar 2009 (PeNSE, National Students' Health Survey) ${ }^{21}$. Students who had difficulties to fill out the questionnaire were assisted by interviewers. This questionnaire collected the following variables: 1) sociodemographic (sex, age, race/ color, live with parents); 2) physical activity outside of school (yes/no); 3) school transport (active: walking, cycling, public buses; and passive: private school buses, motorcycle, car); 4) consumption of school meals (always, sometimes, when it is good, and never), 5) behaviors related to social environment influenced by advertising (visit the mall on the weekends, eat at the mall food court, favorite food advertisement).

The variables were organized according to a conceptual model in which four hierarchical levels of overweight determination were considered: $1^{\text {st }}$ level: demographic and socioeconomic characteristics (number of residents in the household, socioeconomic status, child's sex, child's age, child's race, parents live in household); $2^{\text {nd }}$ level: physical environment (fast-food restaurant in the neighborhood) and social environment (visit the mall on weekends, eat at the mall food court on weekends, interaction between visiting the mall and eating at the mall food court, favorite food advertisements); $3^{\text {rd }}$ level: parental behavior (weekly walking frequency, weekly sports frequency); parental medical history (diabetes, hypertension, hypercholesterolemia, hypertriglyceridemia, and gestational weight gain) and parental nutritional status; $4^{\text {th }}$ level: students' behavior - physical activity outside of school, school transport, consumption of school meals, weekly food intake frequency (French fries, flavored snacks, noodles, chicken nuggets, cookies, stuffed cookies, candies/sweets, soft drinks, processed fruit juice, powdered juice, fruits, salads, fresh and cooked vegetables, milk).

The socioeconomic status of the family was calculated from parental schooling and some family assets (refrigerator, washing machine, computer, internet, motorcycle, car), with scores defined by the Associação Brasileira de Empresas de Pesquisa (ABEP, Brazilian Association of Survey Companies) ${ }^{22}$, and the total score was divided into three categories: high, middle, and low. The original ABEP classification was not used due to the need of keeping the questionnaire as short as possible.

Parental nutritional status, determined by BMl $\left(\mathrm{kg} / \mathrm{m}^{2}\right)$, was classified into: normal weight $\left(<25 \mathrm{~kg} / \mathrm{m}^{2}\right)$, overweight $\left(25.0-29.9 \mathrm{~kg} / \mathrm{m}^{2}\right)$, and obese $\left(\geq 30 \mathrm{~kg} / \mathrm{m}^{2}\right)^{23}$.

School transport was classified as passive (car, motorcycle, and private school buses) and active (walking, cycling, and public buses). Even though some authors consider public buses passive, we considered that our community requires walking to the bus stop, which can be far away.

The food preferences and physical activity questionnaire was tested by administering a preliminary version to ten children with the same 
age as the students in the sample. This pre-test of the questionnaire revealed problems with comprehension, which were corrected. Before administering the final version of the questionnaire, the interviewers were trained as instructed by the training manual, with repeated readings of the questionnaire, role playing, training measuring weight, height, and waist circumference, and administering the new pre-test study. In all, the training process lasted 12 hours, and height and weight were measured by one interviewer and the supervisor. Several meetings and authorizations were necessary to interview the students at school.

The database was created in the software EpiData 3.1 (EpiData Association, Odense, Denmark). Digitization was checked for inconsistencies. Analyses were performed by the Statistical Package for Social Science (SPSS Inc., Chicago, Illinois, United States) version 17.0. For each variable, the proportion of the categories, among cases and controls was compared by the Chi-square statistic, and $p<0.05$ considered significant. The Spearman correlation coefficient identified highly correlated variables. Four variables presented a coefficient correlation higher than 0.500 , thus two interaction variables were created: 1) "parental diabetes" and "parental obesity"; and 2) "going to the mall" and "eating at the mall food court on weekends". For each variable, the crude and adjusted Odds Ratio (OR) and respective 95\% Confidence Interval (95\%IC) was calculated by univariate and multiple logistic regression, respectively. Variables associated with the cases $(p<0.20)$ were included in a multiple logistic regression model. The sequence of variable introduction followed the previously mentioned conceptual model, the first level variables were introduced, and those with $p<0.05$ remained in the model. Then the second level variables were added, and only the significant variables of this level were kept. The process was repeated with the third level variables and just the significant variables of this level were kept. Finally the fourth level variables were added to all significant variables of the previous levels, even though they had lost significance. Significant variables were considered associated with overweight/obesity.

The project was approved by the Research Ethics Committee of the School of Medical Sciences of the Universidade Estadual de Campinas $\left(n^{\circ} 218.725 / 2013\right)$. The Secretary of Education of the city authorized the research at the schools. The principals from each school signed a declaration of agreement with the survey for their school. All study parents were informed about the objectives of the research. They also filled a parental questionnaire and provided authorization for their child to answer a questionnaire and to undergo anthropometric measurements at school. The results of each school, without the students' identification, were sent to each school principal, and they were asked to communicate it to the teachers and parents.

\section{RE S U L T S}

In this sample of third-graders, overweight affected $19.2 \%$ and obesity, $20.2 \%$. Of the overweight and obese students ( $n=201), 51.7 \%$ were male, $58.7 \%$ were 7 or 8 years old, $56.2 \%$ reported being black or brown, $71.6 \%$ lived with both parents, and $42.8 \%$ lived in households with 4 dwellers (Table 1). No statistically significant difference between cases and controls was observed in this table.

In Table 2 overweight and obese children were more likely to go to the mall on weekends $(\mathrm{OR}=1.60 ; 95 \% \mathrm{Cl}=1.06-2.40)$, eat at the mall $(1.67 ; 95 \% \mathrm{Cl}=1.11-2.58)$ and present the interaction of going and eating at the mall ( $O R=1.59 ; 95 \% \mathrm{Cl}=1.06-2.39)$ than normal weight children. No significant differences were found between cases and controls for the other two environmental variables, existence of fast-food restaurants in the neighborhood and children's favorite food advertisement.

When compared with normal weight children, overweight or obese students were more likely to have parents with hypertension, diabetes, obesity, and interaction between diabetes and 
Table 1. Distribution of cases and controls by demographic and socioeconomic variables. Campinas (SP), Brazil, 2013 (N=509).

\begin{tabular}{|c|c|c|c|c|c|c|}
\hline \multirow{2}{*}{ Variables } & \multicolumn{2}{|c|}{ Cases $(n=201)$} & \multicolumn{2}{|c|}{ Cases $(n=308)$} & \multirow{2}{*}{$p$-value } & \multirow{2}{*}{$\begin{array}{c}\text { OR } \\
(95 \% \mathrm{Cl})\end{array}$} \\
\hline & $\mathrm{n}$ & $\%$ & $\mathrm{n}$ & $\%$ & & \\
\hline Schoolchildren's sex & & & & & 0.810 & \\
\hline Male & 104 & 51.7 & 156 & 50.6 & & 1.00 \\
\hline Female & 97 & 48.3 & 152 & 49.4 & & $0.96(0.67-1.37)$ \\
\hline Total & 201 & 100.0 & 308 & 100.0 & & \\
\hline Schoolchildren's age (years) & & & & & 0.840 & \\
\hline $7-8$ & 118 & 58.7 & 183 & 59.6 & & 1.00 \\
\hline $9-10$ & 83 & 41.3 & 124 & 40.4 & & $1.04(0.72-1.49)$ \\
\hline Schoolchildren's race/color & & & & & 0.658 & \\
\hline White/yellow & 88 & 43.8 & 141 & 45.8 & & 1.00 \\
\hline Black/brown & 113 & 56.2 & 167 & 54.2 & & $1.08(0.76-1.55)$ \\
\hline Living with parents & & & & & 0.120 & \\
\hline Father and mother & 144 & 71.6 & 199 & 65.0 & & 1.00 \\
\hline Single parent & 57 & 28.4 & 107 & 35.0 & & $074(0.50-1.08)$ \\
\hline Number of household dwellers & & & & & 0.136 & \\
\hline More than 4 & 65 & 32.3 & 125 & 40.6 & & 1.00 \\
\hline 4 & 86 & 42.8 & 109 & 35.4 & & $1.52(1.00-2.29)$ \\
\hline 1 to 3 & 50 & 24.9 & 74 & 24.0 & & $1.30(0.81-2.07)$ \\
\hline Socioeconomic level & & & & & 0.081 & \\
\hline High & 51 & 26.2 & 57 & 19.1 & & 1.00 \\
\hline Middle & 128 & 65.6 & 204 & 68.2 & & $0.70(0.45-1.09)$ \\
\hline Low & 16 & 8.2 & 38 & 12.7 & & $0.47(0.23-0.94)$ \\
\hline
\end{tabular}

Note: OR: Odds Ratio; 95\%Cl: 95\% Confidence Interval.

Table 2. Distribution of cases and controls according to variables of the physical and social environments. Campinas (SP), Brazil, $2013(\mathrm{~N}=509)$

\begin{tabular}{|c|c|c|c|c|c|c|}
\hline \multirow{2}{*}{ Variables } & \multicolumn{2}{|c|}{ Cases $(n=201)$} & \multicolumn{2}{|c|}{ Controls $(n=308)$} & \multirow{2}{*}{$p$-value } & \multirow{2}{*}{$\begin{array}{c}\text { OR } \\
(95 \% \mathrm{Cl})\end{array}$} \\
\hline & $\mathrm{n}$ & $\%$ & $\mathrm{n}$ & $\%$ & & \\
\hline Fast food restaurant in the neighborhood & & & & & 0.199 & \\
\hline No & 32 & 16.1 & 63 & 20.7 & & 1.00 \\
\hline Yes & 167 & 83.9 & 242 & 79.3 & & $1.36(0.85-2.17)$ \\
\hline Visit the mall on weekends & & & & & 0.024 & \\
\hline No & 46 & 22.9 & 99 & 32.1 & & 1.00 \\
\hline Yes & 155 & 77.1 & 209 & 67.9 & & $1.60(1.06-2.40)$ \\
\hline Eat at the mall food court on weekends & & & & & 0.014 & \\
\hline Do not eat & 42 & 21.8 & 97 & 31.9 & & 1.00 \\
\hline Eat & 151 & 78.2 & 207 & 68.1 & & $1.67(1.06-2.40)$ \\
\hline Interaction visit and eat at the mall on weekends & & & & & 0.025 & \\
\hline Do not go or eat & 100 & 32.8 & 46 & 23.5 & & 1.00 \\
\hline Go and eat & 205 & 67.2 & 150 & 76.5 & & $1.59(1.06-2.39)$ \\
\hline Favorite food advertisement & & & & & 0.112 & \\
\hline Healthy food & 19 & 11.4 & 45 & 17.0 & & 1.00 \\
\hline Energy-dense nutrient-scarce foods & 147 & 88.6 & 219 & 83.0 & & $1.59(0.89-2.83)$ \\
\hline
\end{tabular}

Note: OR: Odds Ratio; 95\% Cl: 95\% Confidence Interval.

obesity. No differences were verified for the other parental characteristics (Table 3).
Table 4 shows some children's behaviors that have been described in the scientific literature 
Table 3. Distribution of cases and controls according to parents' behavior and morbidity. Campinas (SP), Brazil, 2013 (N=509).

\begin{tabular}{|c|c|c|c|c|c|c|}
\hline \multirow{2}{*}{ Variables } & \multicolumn{2}{|c|}{ Cases $(n=201)$} & \multicolumn{2}{|c|}{ Controls $(n=308)$} & \multirow{2}{*}{$p$-value } & \multirow{2}{*}{$\begin{array}{c}\text { OR } \\
(95 \% \mathrm{Cl})\end{array}$} \\
\hline & $\mathrm{n}$ & $\%$ & $\mathrm{n}$ & $\%$ & & \\
\hline Walking & & & & & 0.629 & \\
\hline$\geq 3$ days/week & 33 & 16.7 & 58 & 19.2 & & 1.00 \\
\hline 1 to 2 days/week & 41 & 20.7 & 54 & 17.9 & & $1.33(0.74-2.41)$ \\
\hline No & 124 & 62.6 & 190 & 62.9 & & $1.15(0.71-1.86)$ \\
\hline Play sports & & & & & 0.316 & \\
\hline$\geq 3$ days/week & 16 & 8.1 & 34 & 11.2 & & 1.00 \\
\hline 1 to 2 days/week & 12 & 6.1 & 12 & 4.0 & & $2.13(0.78-5.76)$ \\
\hline No & 170 & 85.9 & 257 & 84.8 & & $1.41(0.75-2.63)$ \\
\hline Total gestational weight gain & & & & & 0.162 & \\
\hline$\leq 10 \mathrm{~kg}$ & 70 & 38.5 & 120 & 45.1 & & 1.00 \\
\hline 11 to $\geq 20 \mathrm{~kg}$ & 112 & 61.5 & 146 & 54.9 & & $1.32(0.90-1.93)$ \\
\hline Hypertension & & & & & 0.024 & \\
\hline No & 149 & 76.0 & 255 & 84.2 & & 1.00 \\
\hline Yes & 47 & 24.0 & 48 & 15.8 & & $1.68(1.07-2.63)$ \\
\hline Hypercholesterolemia & & & & & 0.082 & \\
\hline No & 180 & 91.8 & 263 & 86.8 & & 1.00 \\
\hline Yes & 16 & 8.2 & 40 & 13.2 & & $0.58(0.32-1.08)$ \\
\hline Hypertriglyceridemia & & & & & 0.870 & \\
\hline No & 179 & 93.2 & 278 & 93.6 & & 1.00 \\
\hline Yes & 13 & 6.8 & 19 & 6.4 & & $1.06(0.51-2.21)$ \\
\hline Diabetes Mellitus & & & & & 0.009 & \\
\hline No & 174 & 88.8 & 288 & 95.0 & & 1.00 \\
\hline Yes & 22 & 11.2 & 15 & 5.0 & & $2.43(1.23-4.81)$ \\
\hline Nutritional status & & & & & 0.001 & \\
\hline Normal weight & 58 & 28.9 & 146 & 46.5 & & 1.00 \\
\hline Overweight & 67 & 33.3 & 108 & 35.6 & & $1.51(0.98-2.32)$ \\
\hline Obese & 76 & 37.8 & 54 & 17.8 & & $3.42(2.15-5.44)$ \\
\hline Interaction diabetes-obesity & & & & & 0.011 & \\
\hline Without diabetes or obesity & 181 & 91.0 & 292 & 96.4 & & 1.00 \\
\hline With diabetes and obesity & 18 & 9.0 & 11 & 3.6 & & $2.64(1.22-5.72)$ \\
\hline
\end{tabular}

Note: OR: Odds Ratio; 95\%Cl: 95\% Confidence Interval.

as associated with obesity. Compared with normal weight students, overweight/obese students are 1.6 times more likely to use passive school transport, and 2.8 and 3 times more likely to eat French fries and chicken nuggets, respectively, 3 to 7 days per week, respectively. The low weekly consumption ( $<5$ days per week) of salads, vegetables, and fruits, and the high weekly consumption ( $>3$ days per week) of powdered juice, candies/sweet snacks, and cookies in both groups of children are noteworthy (Table 4).

Table 5 presents the variables adjusted for socioeconomic status, which remained in the hierarchical model. The variables parental nutritional status, school transport, and weekly food consumption of chicken nuggets were directly and independently associated with childhood overweight. Multiple analysis adjusted for economic level showed that overweight/obese children were more likely to eat at the mall (1.55; $95 \% \mathrm{Cl}=1.00-2.40)$, have overweight and obese parents $(\mathrm{OR}=1.71 ; 95 \% \mathrm{Cl}=1.08-2.71$ and 3.55, $95 \% \mathrm{Cl}=2.18-5.80$ respectively), use passive school transport ( $\mathrm{OR}=1.57 ; 95 \% \mathrm{Cl}=1.04-2.36)$, and consume chicken nuggets on 3 or more days per week (OR=3.03; 95\% Cl=1.32-6.95). 
Table 4. Distribution of cases and controls according to the children's behavior. Campinas (SP), Brazil, 2013 (N=509).

\begin{tabular}{|c|c|c|c|c|c|c|}
\hline \multirow{2}{*}{ Variables } & \multicolumn{2}{|c|}{ Cases $(n=201)$} & \multicolumn{2}{|c|}{ Controls $(n=308)$} & \multirow{2}{*}{$p$-value } & \multirow{2}{*}{$\begin{array}{c}\text { OR } \\
(95 \% \mathrm{Cl})\end{array}$} \\
\hline & $\mathrm{n}$ & $\%$ & $\mathrm{n}$ & $\%$ & & \\
\hline Physical activity outside school & & & & & 0.802 & \\
\hline Yes & 129 & 65.4 & 202 & 65.6 & & 1.00 \\
\hline No & 71 & 35.5 & 106 & 34.4 & & $1.05(0.72-1.52)$ \\
\hline School transport & & & & & 0.006 & \\
\hline Active & 87 & 43.3 & 172 & 55.8 & & 1.00 \\
\hline Passive & 114 & 56.7 & 136 & 44.2 & & $1.66(1.16-2.37)$ \\
\hline Consumption of school meals & & & & & 0.118 & \\
\hline Yes & 177 & 88.1 & 284 & 92.2 & & 1.00 \\
\hline No & 24 & 11.9 & 21 & 7.8 & & $1.61(0.88-2.91)$ \\
\hline Flavored snacks & & & & & 0.829 & \\
\hline No & 73 & 37.1 & 106 & 36.1 & & 1.00 \\
\hline 1 to 2 days/week & 86 & 43.7 & 136 & 46.3 & & $0.92(0.61-1.37)$ \\
\hline 3 to 7 days/week & 38 & 19.3 & 52 & 17.7 & & $1.06(0.63-1.77)$ \\
\hline French fries & & & & & 0.009 & \\
\hline No & 104 & 52.5 & 176 & 59.1 & & 1.00 \\
\hline 1 to 2 days/week & 69 & 34.8 & 107 & 35.9 & & $1.09(0.74-1.61)$ \\
\hline 3 to 7 days/week & 25 & 12.6 & 15 & 5.0 & & $2.82(1.42-5.59)$ \\
\hline Chicken nuggets & & & & & 0.012 & \\
\hline No & 138 & 70.4 & 218 & 73.2 & & 1.00 \\
\hline 1 to 2 days/week & 39 & 19.9 & 70 & 23.5 & & $0.88(0.56-1.37)$ \\
\hline 3 to 7 days/week & 19 & 9.7 & 10 & 3.4 & & $3.00(1.36-6.65)$ \\
\hline Noodles & & & & & 0.921 & \\
\hline No & 124 & 63.6 & 194 & 65.1 & & 1.00 \\
\hline 1 to 2 days/week & 55 & 28.2 & 82 & 27.5 & & $1.05(0.70-1.58)$ \\
\hline 3 to 7 days/week & 16 & 8.2 & 22 & 7.4 & & $1.14(0.57-2.25)$ \\
\hline Cookies & & & & & 0.498 & \\
\hline No & 47 & 23.9 & 74 & 24.7 & & 1.00 \\
\hline 1 to 2 days/week & 83 & 42.1 & 138 & 46.2 & & $0.95(0.60-1.49)$ \\
\hline 3 to 7 days/week & 67 & 34.0 & 87 & 29.1 & & $1.21(0.75-1.97)$ \\
\hline Candies & & & & & 0.114 & \\
\hline No & 21 & 10.6 & 17 & 5.7 & & 1.00 \\
\hline 1 to 2 days/week 91 & 91 & 46.0 & 138 & 46.2 & & $0.53(0.27-1.07)$ \\
\hline 3 to 7 days/week 86 & 86 & 43.4 & 144 & 48.2 & & $0.48(0.24-0.97)$ \\
\hline Soft drinks & & & & & 0.104 & \\
\hline No & 19 & 9.6 & 33 & 11.1 & & 1.00 \\
\hline 1 to 2 days/week 83 & 83 & 42.1 & 150 & 50.3 & & $0.97(0.53-1.78)$ \\
\hline 3 to 7 days/week 95 & 95 & 48.2 & 115 & 38.6 & & $1.93(0.98-3.78)$ \\
\hline Ultra processed juice & & & & & 0.651 & \\
\hline No & 108 & 55.1 & 157 & 52.7 & & 1.00 \\
\hline 1 to 2 days/week 46 & 46 & 23.5 & 81 & 27.2 & & $0.83(0.53-1.28)$ \\
\hline 3 to 7 days/week 42 & 42 & 21.4 & 60 & 20.1 & & $1.02(0.64-1.62)$ \\
\hline Powdered juice & & & & & 0.159 & \\
\hline No & 68 & 34.7 & 80 & 26.8 & & 1.00 \\
\hline 1 to 2 days/week 41 & 41 & 21.4 & 68 & 22.7 & & $0.73(0.44-1.20)$ \\
\hline 3 to 7 days/week 86 & 86 & 43.9 & 151 & 50.5 & & $0.67(0.44-1.02)$ \\
\hline Fruits & & & & & 0.983 & \\
\hline 7 days/week & 45 & 22.7 & 70 & 23.3 & & 1.00 \\
\hline 5 to 6 days/week & 30 & 15.2 & 46 & 15.3 & & $0.58(0.29-1.17)$ \\
\hline$<5$ days/week & $\wedge 123$ & 62.1 & 184 & 61.3 & & $0.90(0.57-1.42)$ \\
\hline
\end{tabular}


Table 4. Distribution of cases and controls according to the children's behavior. Campinas (SP), Brazil, 2013 (N=509).

\begin{tabular}{|c|c|c|c|c|c|c|}
\hline \multirow{2}{*}{ Variables } & \multicolumn{2}{|c|}{ Cases $(n=201)$} & \multicolumn{2}{|c|}{ Controls ( $n=308)$} & \multirow{2}{*}{$p$-value } & \multirow{2}{*}{$\begin{array}{c}\text { OR } \\
(95 \% \mathrm{Cl})\end{array}$} \\
\hline & $n$ & $\%$ & $\mathrm{n}$ & $\%$ & & \\
\hline Salads & & & & & 0.285 & \\
\hline 7 days/week & 42 & 22.7 & 56 & 18.7 & & 1.00 \\
\hline 5 to 6 days/week & 17 & 15.2 & 39 & 13.0 & & $0.58(0.29-1.17)$ \\
\hline `5 days/week & 138 & 62.1 & 204 & 68.2 & & $0.90(0.57-1.42)$ \\
\hline Fresh and cooked vegetables & & & & & 0.594 & \\
\hline 7 days/week & 26 & 13.1 & 36 & 12.0 & & 1.00 \\
\hline 5 to 6 days/week & 17 & 8.6 & 34 & 11.3 & & $0.69(0.32-1.50)$ \\
\hline ^<5 days/week & 155 & 78.3 & 230 & 76.7 & & $0.93(0.54-1.61)$ \\
\hline Milk & & & & & 0.372 & \\
\hline 7 days/week & 108 & 54.8 & 182 & 60.7 & & 1.00 \\
\hline 5 to 6 days/week & 14 & 7.1 & 22 & 7.3 & & $1.07(0.53-2.18)$ \\
\hline ^<5 days/week & 75 & 38.1 & 96 & 32.0 & & $1.32(0.90-1.93)$ \\
\hline
\end{tabular}

Note: OR: Odds Ratio; 95\%Cl: 95\% Confidence Interval.

Table 5. Hierarchical model with logistic regression for overweight/obesity in a population of schoolchildren in Campinas (SP), Brazil, $2013(\mathrm{~N}=463)$.

\begin{tabular}{|c|c|c|c|c|c|c|c|c|c|c|c|c|}
\hline \multirow{2}{*}{ Variables } & \multicolumn{3}{|c|}{ First stage $^{*}$} & \multicolumn{3}{|c|}{ Second stage ${ }^{* *}$} & \multicolumn{3}{|c|}{ Third stage ${ }^{* *}$} & \multicolumn{3}{|c|}{ Fourth stage } \\
\hline & OR & $95 \% \mathrm{Cl}$ & $p$ & OR & $95 \% \mathrm{Cl}$ & $p$ & OR & $95 \% \mathrm{Cl}$ & $p$ & OR & $95 \% \mathrm{Cl}$ & $p$ \\
\hline \multicolumn{13}{|c|}{ Socioeconomic level } \\
\hline High & 1.00 & & & 1.00 & & & 1.00 & & & 1.00 & & \\
\hline Middle & 0.71 & $0.45-1.10$ & 0.126 & 0.74 & $0.48-1.19$ & 0.222 & 0.75 & $0.47-1.19$ & 0.220 & 0.81 & $0.50-1.32$ & 0.396 \\
\hline Low & 0.46 & $0.22-0.96$ & 0.039 & 0.53 & $0.25-1.11$ & 0.091 & 0.51 & $0.24-1.09$ & 0.082 & 0.60 & $0.27-1.33$ & 0.211 \\
\hline \multicolumn{13}{|c|}{$\begin{array}{l}\text { Eat at the mall food } \\
\text { court on weekends }\end{array}$} \\
\hline No & & & & 1.00 & & & 1.00 & & & 1.00 & & \\
\hline Yes & & & & 1.55 & $1.00-2.40$ & 0.048 & 1.46 & $0.93-2.38$ & 0.101 & 1.33 & $0.84-2.11$ & 0.220 \\
\hline \multicolumn{13}{|c|}{$\begin{array}{l}\text { Parental nutritional } \\
\text { status }\end{array}$} \\
\hline Normal weight & & & & & & & 1.00 & & & 1.00 & & \\
\hline Overweight & & & & & & & 1.71 & $1.08-2.71$ & 0.021 & 1.64 & $1.03-2.62$ & 0.037 \\
\hline Obese & & & & & & & 3.55 & $2.18-5.80$ & 0.000 & 3.56 & $2.17-5.86$ & 0.000 \\
\hline \multicolumn{13}{|l|}{ School transport } \\
\hline Active & & & & & & & & & & 1.00 & & \\
\hline Passive & & & & & & & & & & 1.57 & $1.04-2.36$ & 0.031 \\
\hline \multicolumn{13}{|c|}{$\begin{array}{l}\text { Weekly consumption } \\
\text { of chicken nuggets }\end{array}$} \\
\hline No & & & & & & & & & & 1.00 & & \\
\hline 1 to 2 days/week & & & & & & & & & & 0.79 & $0.48-1.29$ & 0.339 \\
\hline 3 to 7 days/week & & & & & & & & & & 3.03 & $1.32-6.95$ & 0.009 \\
\hline
\end{tabular}

Note: ${ }^{*}$ Adjusted OR by socioeconomic level; ${ }^{* *}$ Adjusted OR by all variables on the table: level of significance in bold. OR: Odds Ratio; 95\%Cl: 95\% Confidence Interval.

\section{I S C U S S I O N}

Although our sample consists of students from half the randomly chosen municipal public schools, participation in the study was low $(48.0 \%)$, so we cannot affirm that the study overweight/obesity frequency (39.5\%) corresponds to the prevalence of this problem in the city. This 
frequency is more than double that of another study from the same city, conducted in 2002 with students aged 7 to 17 years ${ }^{17}$; consistent with the macro-Southeast region's prevalence $(39.7 \%)^{7}$; and also similar to the prevalence reported by a survey in the city of Santos (SP) with children aged 6 to 10 years $(38.9 \%)^{24}$. The overweight/obesity trend significantly increased from 1980 to 2013, and in developing countries it is still growing ${ }^{25}$.

The study accomplished its objective of determining the variables directly and independently associated with overweight/obesity among thirdgraders. Cases were more likely than controls to have overweight or obese parents. This association was expected, since it has been reported by Brazilian and foreign studies ${ }^{18,19,26-28}$. Although the data suggest a genetic component, parental nutritional status may be an indicator of environmental characteristics shared with children, such as food habits and level of physical activity, both of which can be important risk factors for overweight.

Overweight/obese children were less likely to be from low socioeconomic class families. This has been generally observed in developing countries. However, while some authors ${ }^{29,30}$ have made similar findings, others have found a higher likelihood of childhood overweight/obesity in poor families, more consistently seen in developed countries $^{31}$, but also observed in Brazil ${ }^{24,26}$.

Regarding weekly food intake frequency, only chicken nuggets, classified as an ultra-processed product, was associated with excess weight. A cohort study of children aged 9-14 years in the United States found that children who increased their intake of fried foods away from home for one year gained more weight than expected from height gain and sexual maturation, and also have poorer diet quality ${ }^{32}$. Ultra-processed products are designed to have high palatability and satiety factors, long shelf life, and not require culinary preparation, which make them practical and convenient ${ }^{33}$. The convenience, palatability, and affordability of these products compared with unprocessed or minimally processed foods have stimulated their consumption and contributed to increase the rates of obesity and associated comorbidities. When ultra-processed products are followed by insufficient consumption of fruits and vegetables, they contribute to diet/energy imbalance ${ }^{34}$. In Florianópolis (SC) less than $5 \%$ of the children aged 7 to 14 years eat at least two fruits and three vegetables per day ${ }^{35}$. During childhood, household consumption of ultraprocessed products contributes to the formation of unhealthy eating habits, since the experiences and exposures that occur during this life period have long-term repercussions on health and behaviors. Given that individuals with low socioeconomic status have less access to healthy foods ${ }^{36}$, healthier eating behaviors require that local public policy authorities work to assure the availability of fresh fruit and vegetables at accessible prices, incentivizing local grocers, farmers' markets, and even local family farms.

Although Veerman et al. ${ }^{37}$ estimate that one-third of obese children in the United States would not be obese if they had not been exposed to unhealthy food advertising on TV, our variable "asking parents to buy foods advertised on Television (TV)", was not significantly associated with excess weight (data not shown), but the overweight/obese group reported a higher but not significant preference for unhealthy food advertisement (88.9\%). Still, "going to and eating at the mall" was significantly associated with excess weight. The food industry's high investment in marketing has been indirectly described by Monteiro ${ }^{38}$, who recorded four TV channels during one year and found 290 pieces of food publicity for children, representing $72.0 \%$ of this type of advertisement. The main advertised products were fast foods (hamburger, French fries), ice-creams, flavored snacks, cookies, candies, soft drinks, and artificial juice. The powerful influence of this industry has been difficult to overcome, and education initiatives need to address it creatively and without funds.

Like other studies, the study overweight/ obese third-graders are more likely to use passive 
school transport ${ }^{27,30}$. Recent studies have found that active school transport was predictive of lower $\mathrm{BMI}^{39}$ and increased child cardiovascular endurance during physical activity ${ }^{40}$; thus, active school transport seems like an important strategy for the promotion of physical activity and prevention of childhood overweight. However, to encourage active transport, it is essential to consider urban safety ${ }^{41}$. In Campinas (SP) there are no bicycle pathways, in many neighborhoods sidewalks are inappropriate, and violence inhibits people from using public places.

Regarding the study limitations, the quality of parent-reported dietary data may have reduced the accuracy, since most parents work and do not see their children during the day. Notwithstanding, the information provided by 7 - to 10-year-olds may be more imprecise than that provided by the parents because they cannot quantify food well and confuse what they like to eat with what they actually ate.

Despite these limitations, our observations are guaranteed by our sample size. For the variables and categories eat at the mall, parental obesity, passive school transport, and consumption of chicken nuggets on 3 or more days a week, our sample size was bigger than the estimated for the difference in the proportions between cases and controls, using $\alpha=0.05, \beta=0.1$, and power of 0.9. For low socioeconomic level, our sample size was compatible with one estimated with $\alpha=0.02, \beta=0.2$, and power of 0.8 . Only overweight among parents was not confirmed by our sample size. Even the sample size estimated a posteriori with $33.5 \%$ prevalence of excess weight in a national sample of children aged 5 to 9 years $^{3}$ and with the study prevalence $39.5 \%$, using $\alpha=0.05, \beta=0.1$, and power of 0.9 , the sample size was 493, and thus appropriate.

The study strengths include its heterogeneity related to geographic distribution, race/color, and socioeconomic status, which allows generalization to a larger population of children aged 7 to 10 years, students of public schools located in large cities of the Brazilian southeastern region.
Additionally, data collection and digitization procedures guarantied reliable data. Also important is that the conceptual model used for hierarchical analysis using multiple logistic regression enabled the consideration and control of variables at different levels of proximity to overweight/obesity. The strength of the study relies on the fact that the study associations are biologically and epidemiologically plausible and have been reported by other authors.

\section{CONCLUSION}

The significant associations of child overweight/obesity with parental obesity, family behaviors, food habits, and physical activity confirm the complexity of childhood obesity. Hence, we emphasize the need to prevent childhood overweight using measures that involve the child's family, especially related to the adequacy of parental nutritional status; the need of changes in eating habits; and mainly the importance of discouraging the consumption of ultra-processed products. Parents and children must be simultaneously encouraged to practice physical activity on a broader scale using whatever methods are available, such as active school transport. However, in order to promote active school transport it is essential to invest in public safety and walking and cycling paths. Moreover, it is desirable to restrict advertisements of ultraprocessed products and to provide available and affordable unprocessed, minimally processed, and organic foods, especially in poorer neighborhoods. Finally, studies are needed to assess and monitor government promotion and prevention of overweight in all ages, especially in children and adolescents.

\section{A C KNOWLEDGMENTS}

The authors thank the Public Education Department of Campinas, the dietitians of the school meals' program in Campinas, all principals, teachers, parents, and students that kindly authorized and participated in the survey. The authors thank the 
interviewers for the collaboration with the fieldwork. Finally, we thank Coordenação de Aperfeiçoamento de Pessoal de Nivel Superior for the master's degree scholarship.

\section{CONTRIBUTORS}

JMTB CAMARGO contacted schools, performed anthropometric measurements, administered the questionnaires, performed the statistical analyses, and wrote the manuscript. L MARÍN-LEÓN designed the study, reviewed the statistical analyses, and wrote the manuscript.

\section{REFERE N CES}

1. World Health Organization. Childhood overweight and obesity. Geneva: WHO; 2014 [cited 2014 May 25]. Available from: http://www.who.int/ dietphysicalactivity/childhood/en

2. Batista Filho M, Rissin A. A transição nutricional no Brasil: tendências regionais e temporais. Cad Saúde Pública. 2003; 19(Supl. 1):S181-S91. http://dx.doi. org/10.15 90/S0102-311X2003000700019

3. Instituto Brasileiro de Geografia e Estatística. Pesquisa de orçamentos familiares 2008-2009: antropometria e estado nutricional de crianças, adolescentes e adultos no Brasil. Rio de janeiro: IBGE; 2010 [acesso 2014 maio 25]. Disponível em: http:// www.ibge.gov.br/home/estatistica/populacao/ condicaodevida/pof/2008_2009_encaa/default. shtm

4. World Health Organization. Obesity: Preventing and managing the global epidemic: Report of a WHO consultation. Geneva: WHO; 2000 [cited 2014 May 25]. Available from: http://apps.who.int/iris/handle/ $10665 / 42330$

5. Erickson SJ, Robinson TN, Haydel F, Killen JD. Are overweight children unhappy? Body mass index, depressive symptoms, and overweight concerns in elementary school children. Arch Pediatr Adolesc Med. 2000; 154(9):931-5. http://dx.doi.org/10.10 01/archpedi.154.9.931

6. Davidson KK, Birch LL. Child and parent characteristics as predictors of change in girls' body mass index. Int J Obes Relat Metab Disord. 2001; 25(12):1834-42. http://dx.doi.org/10.1038/sj.ijo.0801835

7. Instituto Brasileiro de Geografia e Estatística. Pesquisa de orçamentos familiares 2008-2009: análise do consumo alimentar pessoal no Brasil. Rio de Janeiro: IBGE; 2010 [acesso 2014 maio 25]. Disponível em: from: http://www.ibge.gov.br/home/estatistica/ populacao/condicaodevida/pof/2008_2009_encaa/ default.shtm
8. Monteiro CA, Cannon G. The impact of transnational "big food" companies on the South: A view from Brazil. PLoS Med. 2012; 9(7):e1001252. http://dx. doi.org/10.1371/journal.pmed.1001252

9. Souza AM, Pereira RA, Yokoo EM, Levy RB, Sichieri R. Alimentos mais consumidos no Brasil: Inquérito Nacional de Alimentação 2008-2009. Rev Saúde Pública. 2013; 47(Supl. 1):190S-9S. http://dx.doi. org/10.1590/S0034-89102013000700005

10. Hallal PC, Bertoldi AD, Gonçalves H, Victora CG. Prevalência de sentarismo e fatores associados em adolescentes de 10-12 anos de idade. Cad Saúde Pública. 2006; 22(6):1277-87. http://dx.doi.org/10. 1590/S0102-311X2006000600017

11. Center of Disease Control and Prevention. Increasing physical activity: A report on recommendations of the Task Force on Community Preventive Services. Atlanta: Task Force on Community Preventive Services; 2001 [cited 2014 May 25]. Available from: http://www.cdc.gov/mmwr/preview/mmwrhtml/ rr5018a1.htm

12. Dollman J, Norton K, Norton L. Evidence for secular trends in children's physical activity behavior. $\mathrm{Br} J$ Sports Med. 2005; 39(12):892-7. http://dx.doi.org/ 10.1136/bjsm.2004.016675

13. Arango CM, Parra DC, Eyler A, Sarmiento O, Mantilla SC, Gomez LF, et al. Walking or bicycling to school and weight status among adolescents from Montería, Colombia. J Phys Act Health. 2011; 8(Suppl. 2):S171-7.

14. Kelly B, Halford JCG, Boyland EJ, Chapman K, Bautista-Castaño I, Berg C, et al. Television food advertising to children: A global perspective. Am J Public Health. 2010; 100(9):1730-6. http://dx.doi. org/10.20105/AJPH.2009.179267

15. World Health Organization. Growth reference 519 years. Geneva: WHO; 2007 [cited 2014 Mar 5]. Available from: http://www.who.int/growthref/ who2007_bmi_for_age/en

16. Prefeitura Municipal de Campinas. Núcleo de Ação Educativa Descentralizada (NAED). Campinas: Prefeitura Municipal; 2013 [acesso 2013 mar 5]. Disponível em: http://www.campinas.sp.gov.br/ governo/educacao/naeds/index.php

17. Cocetti M. Peso, altura, IMC e composição corporal de escolares de 7 a 17 anos no município de Campinas - SP [doutorado]. Campinas: Universidade Estadual de Campinas; 2006.

18. Granich J, Rosenberg M, Knuiman M, Timperio A. Understanding children's sedentary behaviour: A qualitative study of the family home environment. Health Educ Res. 2010; 25(2):199-210. http://dx. doi.org/10.1093/her/cyn025

19. Reis EC, Kip KE, Marroquin OC, Kiesau M, Hipps Jr. L, Peters RE, et al. Screening children to identify families at increased risk for cardiovascular disease. Pediatrics. 2006; 118(6):e1789-97. 
20. Bernardo CO, Pudla KJ, Longo GZ, Vasconcelos FAG. Fatores associados ao estado nutricional de escolares de 7 a 10 anos: aspectos sociodemográficos, de consumo alimentar e estado nutricional dos pais. Rev Bras Epidemiol. 2012; 15(3):11. http:// dx.doi.org/ 10.1590/S1415-790X2012000300018

21. Instituto Brasileiro de Geografia e Estatística. Pesquisa Nacional de Saúde do Escolar. Rio de Janeiro: IBGE; 2010 [acesso 2014 mar 5]. Disponível em: http://www.ibge.gov.br/home/estatistica/ populacao/pense

22. Associação Brasileira de Empresas de Pesquisa. Critério de classificação econômica Brasil. São Paulo: Abep; 2011 [acesso 2014 mar 5]. Disponível em: http://www.abep.org/new/criterioBrasil.aspx

23. World Health Organization. Global database on body mass index. Geneva: WHO; 2004 [cited 2014 Mar 5]. Available from: http://apps.who.int/bmi/ index.jsp?introPage=intro_3.html

24. Cremm EC, Leite FHM, Abreu DS, Oliveira MA, Scagliusi FB, Martins PA. Factors associated with overweight in children living in the neighbourhoods of an urban area of Brazil. Public Health Nutr. 2012; 15(6):1056-64.

25. Ng M, Fleming T, Robinson M, Thomson B, Graetz N, Margono $C$, et al. Global, regional, and national prevalence of overweight and obesity in children and adults during 1980-2013: A systematic analysis for the Global Burden of Disease Study 2013. Lancet. 2014; 384(9945):766-81.

26. Guimarães LV, Barros MBA, Martins MSAS, Duarte EC. Fatores associados ao sobrepeso em escolares. Rev Nutr. 2006; 19(1):5-17. http://dx.doi.org/10.1590/ S1415-52732006000100001

27. Rodrigues PA, Marques MH, Chaves MGAM, Souza CF, Carvalho MF. Prevalência e fatores associados a sobrepeso e obesidade em escolares da rede pública. Ciênc Saúde Coletiva. 2011; 16(Supl. 1):7. http://dx.doi.org/10.1590/\$14138123201100070 0094

28. Lazzeri G, Pammolli A, Pilato V, Giacchi MV. Relationship between 8/9-yr-old school children BMI, parents' BMI and educational level: A cross sectional survey. Nutr J. 2011; 19(10):79. http:// dx.doi.org/10.1186/1475-289-10-76

29. Farias ES, Santos AP, Farias-Júnior JC, Ferreira CRT, Carvalho WRG, Gonçalves EM, et al. Excess weight and associated factors in adolescents. Rev Nutr. 2012; 25(2):229-36. http://dx.doi.org/10.1590/S14 15-52732012000200005

30. Guedes DP, Miranda Neto JT, Almeida MJ, Silva AJRM. Impacto de fatores sociodemográficos e comportamentais na prevalência de sobrepeso e obesidade de escolares. Rev Bras Cineantropom Desemp Hum. 2010; 12(4):221-31.

31. Rose D, Bodor JN. Household food insecurity and overweight status in young school children: Results from the early childhood longitudinal study. Pediatrics. 2006; 117(2):464-73.

32. Taveras EM, Berkey CS, Rifas-Shirman SL, Ludwig DS, Rockett $\mathrm{HRH}$, Field $A E$, et al. Association of consumption of fried food away from home with body mass index and diet quality in older children and adolescents. Pediatrics. 2005; 116(4):e518-24. http://dx.doi.org/10.1542/peds.2004-2732

33. Monteiro CA. Nutrition and health. The issue is not food, nor nutrients, so much as processing. Public Health Nutr. 2009; 12(5):729-31. http://dx.doi.org/ 10.1017/S1368980009005291

34. Raynor H, Van Walleghen EL, Osterholt KM, Hart CN, Jelalian E, Wing RR, et al. The relationship between child and parent food hedonics and parent and child food group intake in overweight/obese children. J Am Diet Assoc. 2011; 111(3):425-30.

35. Galego CR, D'Avila GL, Vasconcelos FAG. Factors associated with the consumption of fruits and vegetables in schoolchildren aged 7 to 14 years of Florianópolis, South of Brazil. Rev Nutr. 2014; 27(4):413-22. http://dx.doi.org/10.1590/1415-527 32014000400003

36. Belon AP, Nykiforuk C. Possibilities and challenges for physical and social environment research in Brazil: A systematic literature review on health behaviors. Cad Saúde Pública. 2013; 29(10):1955-73.

37. Veerman JL, Van Beeck EF, Barendregt J, Mackenbach JP. By how much would limiting TV food advertising reduce childhood obesity? Eur J Public Health. 2009; 19(4):365-9. http://dx.doi.org/10.1093/ eurpub/ckp039

38. Monteiro RA. Influência de aspectos psicossociais e situacionais sobre a escolha alimentar infantil [doutorado]. Brasília: Universidade de Brasília; 2009.

39. Pabayo R, Gauvin L, Barnett T, Nikiema B, Seguin L. Sustained active transportation is associated with a favorable study body mass index trajectory across the early school years: Findings from Quebec longitudinal study of child development birth cohort. Prev Med. 2010; 50(Suppl. 1):S59-64. http:// dx.doi.org/10.1016/j.ypmed.2009.08.014

40. Davison K, Werder J, Lawson C. Children's active commuting to school: Current knowledge and future directions. Pre Chronic Dis. 2008; 5(3):A100.

41. Belon AP, Nieuwendyk LM, Vallianatos $\mathrm{H}$, Nykiforuk Cl. How community environment shapes physical activity: Perceptions revealed through the PhotoVoice method. Soc Sci Med. 2014; 116:10-21. http://dx.doi.org/10.1016/j.socsciemed.2014. 06.207 
